\title{
Morphological Characterization and Genetic Analysis of Finger Millet (Eleusine coracana (L.) Gaertn) Germplasm
}

\author{
Shivangi Negi ${ }^{{ }^{*}}$, Vineet Kumar ${ }^{2}$ and Arun Bhatt ${ }^{2}$ \\ ${ }^{1}$ Dept. of Seed Science and Technology, ${ }^{2}$ Dept. of Crop Improvment, V. C. S. G. Uttarakhand University of Horticulture and \\ Forestry, Bharsar, Uttarakhand (246 123), India
}

\section{Corresponding Author}

Shivangi Negi

e-mail: shivanginegi002@gmail.com

\author{
Article History \\ Manuscript No. AR1732 \\ Received in $10^{\text {th }}$ November, 2016 \\ Received in revised form $18^{\text {th }}$ May, 2017 \\ Accepted in final form $6^{\text {th }}$ June, 2017
}

\begin{abstract}
The present investigation was conducted during kharif, 2014 at Research Block, Dept. of Crop Improvement, V.C.S.G. Uttarakhand University of Horticulture and Forestry, College of Forestry, Ranichauri Campus with thirty-five diverse genotypes of finger millet including three checks viz., PRM-1, PRM-2 and VL-149 laid out in Randomized Complete Block Design. Observations were recorded for fourteen morphological traits and the data were analyzed for variability, heritability and expected genetic advance. Computation of genotypic, phenotypic and environmental variances, genotypic coefficient of variance, phenotypic coefficient of variation and environmental coefficient of variation, heritability (in broad sense) and genetic advance were statistically worked out to understand the nature and extent of variability in expression of different characters prevailed in population and that led to facilitate selection for various traits for identifying desired genotyped suitable for hills. Analysis of variance revealed highly significant differences among all thirty-five genotypes with a wide range of mean values for different characters. There was sufficient variability found for all the characters among the various genotypes which could offer great scope for improvement. Genotypic and phenotypic variances were highest for biological yield per plant followed by plant height, days to 50 per cent flowering and harvest index. Hence, these characters are more suitable for selection procedure. High heritability coupled with high genetic advance was observed for biological yield per plant, plant height and days to 50 per cent flowering. Direct selection for these characters would be effective as heritability and genetic advance might be due to additive gene interaction.
\end{abstract}

Keywords: Diverse genotype, variability, heritability, genetic advance, variance

\section{Introduction}

Finger millet (Eleusine coracana (L.) Gaertn. $2 n=4 x=36$ ) belongs to the family Poaceae, and is widely cultivated in the arid and semi-arid regions of the world. The term Eleusine is derived from Eleusis, an old epic city sacred to Demater, the greek deity presiding over agriculture. The term coracana is derived from kurukkan, the singhali name of the grain. The word Ragi is derived from Sanskrit word "Rajika" means red. Millets are small seeded grasses, and are distributed in about 10 genera and 20 species. Most of the small millets have their origin mainly in Asia and Africa. The most important domesticated areas are East Asia, India sub-continent and Ethiopian high lands of Africa. It is cultivated mostly as a rainfed crop for its valued food grains, dry fodder and adaptability to wide range of geographical areas (Ulaganathan and Nirmalkumari, 2014). Ragi is commonly called as "Nutritious millet" as the grains are nutritionally superior to many cereals providing fair amount of proteins, minerals, calcium and vitamins in abundance to the people. It is the cheapest and preferred food crop of economically suppressed but physically hard working people. It is cultivated mostly as a rainfed crop in India under diverse production environments (Patil and Mane, 2013). Being rich in protein, iron and calcium, finger millet severs as an important staple food for rural populations in developing tropical countries where calcium deficiency and anaemia are widespread (Owere et al., 2015). In order to achieve the goal of increased production by increasing the yield potential of genotypes, knowledge of variability, inheritance, direction and magnitude of association between various traits and their stable performance is essential for a plant breeder.

In general, genetic variability, heritability and genetic advance are pre-requisites for breeding program and provide opportunity to plant breeder for selecting high yielding genotypes or to combine or transfer genes having desirable traits. Heritability and genetic advance are important factors 
to determine the success of selection in breeding programs. Improvement in any crop usually involves exploiting the genetic variability in specific traits. Simultaneous improvement of these traits depends on the nature and degree of association between traits. Heritability is of interest to plant breeders primarily as a measure of the value of selection for a particular character in various types of progenies and as an index of transmissibility. If the percentage is large, the character is heritable but if it is small, environment is correspondingly prominent in the character expression (Hayes et al., 1955). There is a great genetic variation among varieties and germplasm of finger millet. Besides the availability of genetic diversity, their characterization is essential for the effective utilization in the crop improvement (Goswami et al., 2015).

Grain yield is a complex character influence by large number of other component characters. Knowledge on the association between yield and other biometric traits and also among component traits helps in improving the efficiency of selection. Therefore, investigating and identifying plants for the genetic variation available in the breeding materials is the first step of plant breeding and so vital for successful crop improvement programme. The present investigation is a step towards the exploring variability among the finger millet germplasm and studying the genetic parameters of the populations.

\section{Materials and Methods}

The investigation was conducted during kharif, 2014 at Research Block, Department of Crop Improvement, V.C.S.G. Uttarakhand University of Horticulture and Forestry, College of Forestry, Ranichauri Campus with thirty-five diverse genotypes of finger millet including three checks viz., PRM-1, PRM-2 and VL-149. This is situated at humid and temperate type of climate with chilled winters. The mean monthly minimum and maximum temperature during finger millet crop period (June to November) varies between $3.2^{\circ} \mathrm{C}$ to $12.0^{\circ} \mathrm{C}$ and $3.2{ }^{\circ} \mathrm{C}$ to $11.8^{\circ} \mathrm{C}$, respectively. The average annual rainfall of $1230 \mathrm{~mm}$ was experienced a last 20 years. The accessions were obtained from Department of Crop Improvement, College of Forestry Ranichauri, Project Coordinator Unit of All India Small Millet Improvement Project Bangalore and National Bureau of Plant Genetic Resources (NBPGR) New Delhi. The experiment was laid out in Randomized Complete Block Design with three replications.

Observation were recorded from five randomly selected plants in each accession for fourteen characters viz., days to $50 \%$ flowering, days to maturity, plant height $(\mathrm{cm})$, flag leaf area $\left(\mathrm{cm}^{2}\right)$, peduncle length $(\mathrm{cm})$, number of leaves on main culm, number of productive tillers plant ${ }^{-1}$, number of fingers ear $^{-1}$, finger length $(\mathrm{cm})$, ear length $(\mathrm{cm})$, biological yield plant ${ }^{-1}$ (g), harvest index (\%), 1000 seed weight (g), grain yield plant ${ }^{-1}$ (g). The data collected for all quantitative characters were subjected to analysis of variance according to the method recommended by Cochran and Cox (1992). Phenotypic and genotypic coefficients of variation were computed according to the method suggested by Burton and Devane (1953). Heritability in broad sense was calculated as per the formula given by Allard (1960). Genetic advance was expressed by using the formula suggested by Johnson et al. (1955).

\section{Results and Discussion}

On the visual observation ear colour categorized in two groups green and purple. Out of thirty-five genotypes, most of the entries showed green ear head while EC-130783, IC-354422, IC-354381, EC-522488, IC-308868 and EC-522485 showed purple ear colour head.

\subsection{Variance}

Analysis of variance revealed that mean squares due to genotypes were highly significant for all the characters under study (Table 1). It indicates that the germplasm tested were highly variable. Substantial variations in finger millet have been also reported in previous study (Dapke et al., 2014; Kumari et al., 2015).

Table 1: Analysis of variance for 14 characters in 35 finger millet (Eleusine coracana (L.) Gaertn.) genotypes

\begin{tabular}{|c|c|c|c|}
\hline \multirow[t]{2}{*}{ Character } & \multicolumn{3}{|c|}{ Mean Sum of Square (MSS) } \\
\hline & $\begin{array}{l}\text { Repli- } \\
\text { cation }\end{array}$ & $\begin{array}{l}\text { Treat- } \\
\text { ment }\end{array}$ & Error \\
\hline Degree of freedom & 2 & 34 & 68 \\
\hline Days of $50 \%$ flowering & 0.63 & $170.09^{* *}$ & 1.94 \\
\hline Days to maturity & 1.72 & $24.50^{* *}$ & 0.57 \\
\hline Plant height $(\mathrm{cm})$ & 19.82 & $227.16^{* *}$ & 10.82 \\
\hline Flag leaf area $\left(\mathrm{cm}^{2}\right)$ & 0.75 & $32.33^{* *}$ & 0.47 \\
\hline Peduncle length $(\mathrm{cm})$ & 0.86 & $10.29^{* *}$ & 0.12 \\
\hline No. of leaves on main culm & 0.03 & $2.33^{* *}$ & 0.05 \\
\hline $\begin{array}{l}\text { No. of productive tillers } \\
\text { plant }^{-1}\end{array}$ & 0.08 & $1.63^{* *}$ & 0.02 \\
\hline Fingers per ear-1 & 0.27 & $1.29^{* *}$ & 0.09 \\
\hline Finger length $(\mathrm{cm})$ & 0.85 & $17.00^{* *}$ & 0.47 \\
\hline Ear length $(\mathrm{cm})$ & 0.42 & $17.08^{* *}$ & 0.30 \\
\hline Biological yield plant ${ }^{-1}(\mathrm{~g})$ & 6.65 & $387.25^{* *}$ & 1.56 \\
\hline Harvest index (\%) & 7.88 & $38.15^{* *}$ & 4.56 \\
\hline 1000 seed weight $(\mathrm{g})$ & 0.003 & $0.16^{* *}$ & 0.003 \\
\hline Grain yield plant ${ }^{-1}(\mathrm{~g})$ & 0.47 & $7.58^{* *}$ & 0.48 \\
\hline
\end{tabular}

*Significant at $(p=0.05)$ level; ${ }^{* *}$ Significant at $(p=0.01)$ level

The estimates of mean, range, genotypic variance, phenotypic variance, genotypic coefficient of variation (GCV), phenotypic coefficient of variation (PCV), heritability in broad sense $\left(h^{2}\right)$ and genetic advance are presented in Table 2.

\subsection{Coefficient of Variation}

Highest genotypic and phenotypic coefficients of variation 
Table 2: Estimates of variance and genetic parameters for 14 characters in 35 finger millet (Eleusine coracana (L.) Gaertn.) genotypes

\begin{tabular}{|c|c|c|c|c|c|c|c|c|c|c|}
\hline \multirow{2}{*}{$\begin{array}{l}\text { Sl. } \\
\text { No. }\end{array}$} & \multirow[t]{2}{*}{ Characters } & \multirow{2}{*}{$\begin{array}{c}\text { Gen- } \\
\text { eral } \\
\text { mean }\end{array}$} & \multicolumn{3}{|c|}{ Variance } & \multicolumn{3}{|c|}{ Coefficient of variance } & \multirow{2}{*}{$\begin{array}{c}\text { Heri- } \\
\text { tability } \\
\left(\mathrm{h}^{2}\right)\end{array}$} & \multirow{2}{*}{$\begin{array}{l}\text { Gene- } \\
\text { tic Ad- } \\
\text { vance } \\
\text { (GA) }\end{array}$} \\
\hline & & & $\begin{array}{c}\text { Geno- } \\
\text { typic } \\
\sigma^{2} g\end{array}$ & $\begin{array}{l}\text { Pheno- } \\
\text { typic } \\
\sigma^{2} p\end{array}$ & $\begin{array}{c}\text { Environ- } \\
\text { ment } \\
\sigma^{2} \mathrm{e}\end{array}$ & $\begin{array}{c}\text { Geno- } \\
\text { typic } \\
(\mathrm{GCV})\end{array}$ & $\begin{array}{l}\text { Pheno- } \\
\text { typic } \\
\text { (PCV) }\end{array}$ & $\begin{array}{c}\text { Environ- } \\
\text { ment } \\
(\mathrm{ECV})\end{array}$ & & \\
\hline 1. & Days of $50 \%$ flowering & 99.73 & 56.05 & 57.99 & 1.94 & 7.51 & 7.64 & 1.40 & 96.65 & 15.16 \\
\hline 2. & Days to maturity & 156.04 & 7.98 & 8.55 & 0.58 & 1.81 & 1.87 & 0.49 & 93.26 & 5.62 \\
\hline 3. & Plant height $(\mathrm{cm})$ & 86.56 & 72.11 & 82.94 & 10.83 & 9.81 & 10.52 & 3.80 & 86.95 & 16.31 \\
\hline 4. & Flag leaf area $\left(\mathrm{cm}^{2}\right)$ & 22.99 & 10.62 & 11.09 & 0.47 & 14.17 & 14.49 & 2.99 & 95.74 & 6.57 \\
\hline 5. & Peduncle length $(\mathrm{cm})$ & 8.23 & 3.39 & 3.52 & 0.13 & 22.38 & 22.80 & 4.38 & 96.31 & 3.72 \\
\hline 6. & No. of leaves on main culm & 10.04 & 0.76 & 0.81 & 0.05 & 8.68 & 8.98 & 2.29 & 93.51 & 1.74 \\
\hline 7. & No. of productive tillers plant ${ }^{-1}$ & 2.69 & 0.54 & 0.56 & 0.03 & 27.24 & 27.92 & 6.14 & 95.17 & 1.47 \\
\hline 8. & No. of fingers ear ${ }^{-1}$ & 7.49 & 0.40 & 0.49 & 0.09 & 8.47 & 9.38 & 4.03 & 81.50 & 1.18 \\
\hline 9. & Finger length (cm) & 8.17 & 5.51 & 5.99 & 0.48 & 28.72 & 29.94 & 8.44 & 92.05 & 4.64 \\
\hline 10. & Ear length $(\mathrm{cm})$ & 9.15 & 5.59 & 5.90 & 0.31 & 25.83 & 26.53 & 6.04 & 94.82 & 4.74 \\
\hline 11. & Biological yield plant ${ }^{-1}(\mathrm{~g})$ & 38.09 & 128.56 & 130.13 & 1.57 & 29.77 & 29.95 & 3.29 & 98.79 & 23.22 \\
\hline 12. & Harvest index (\%) & 15.25 & 11.20 & 15.76 & 4.57 & 21.94 & 26.04 & 14.02 & 71.03 & 5.81 \\
\hline 13. & 1000 seed weight (g) & 2.61 & 0.05 & 0.06 & 0.00 & 8.78 & 9.05 & 2.16 & 94.29 & 0.46 \\
\hline 14. & Grain yield plant $^{-1}(\mathrm{~g})$ & 5.65 & 2.37 & 2.85 & 0.49 & 27.24 & 29.92 & 12.38 & 82.89 & 2.88 \\
\hline
\end{tabular}

were observed for biological yield plant ${ }^{-1}(29.77 \%$ and $29.95 \%)$ followed by finger length (28.72\% and $29.94 \%)$, productive tillers plant ${ }^{-1}(27.24 \%$ and $27.92 \%)$, grain yield plant $^{-1}$ (27.24\% and $\left.29.92 \%\right)$, peduncle length $(22.38 \%$ and $22.80 \%$ ) and harvest index (21.94\% and $26.04 \%$ ). Hence, these characters are more suitable for direct selection procedure. Corresponding to the findings of present investigation high GCV and PCV have also been reported by Bisht et al. (2015); Kumari et al. (2015); Das et al. (2016). Moderate GCV and PCV were not found in present study while flag leaf area (14.17\% and $14.49 \%$ ), plant height (9.81\% and $10.52 \%), 1000$ seed weight (8.78\% and $9.05 \%)$, no. of leaves on main culm (8.68\% and $8.98 \%)$, no. of fingers ear ${ }^{-1}(8.47 \%$ and $9.38 \%)$, days to $50 \%$ flowering ( $7.51 \%$ and $7.64 \%$ ) and days to maturity (1.81\% and $0.49 \%)$ showed the lowest GCV and PCV. Similar results also reported by Lule et al. (2012); Kadar et al. (2013), Suryanarayana et al. (2014); Ulaganathan et al. (2014); Bisht et al. (2015) in finger millet.

\subsection{Heritability}

The genotypes under study showed high heritability values for all the characters under study. Highest heritability was recorded for biological yield per plant $(98.79 \%)$ followed by days to $50 \%$ flowering $(96.65 \%)$, peduncle length $(96.31 \%)$, flag leaf area (95.74\%), productive tillers plant ${ }^{-1}(95.71 \%)$, ear length (94.82\%), 1000 seed weight (94.29\%), number of leaves on main culm (93.51\%), days to maturity (93.26\%), finger length $(92.05 \%)$, plant height $(86.95 \%)$, grain yield plant $^{-1}$ $(82.89 \%)$ and number of fingers ear ${ }^{-1}(81.50 \%)$. Heritability estimates were more than $80 \%$ for all the characters studied except harvest index which indicates that these characters were relatively less influenced by environmental conditions and phenotypic selection would be effective for these characters with high probability of success. Similarly in finger millet high heritability for all the characters reported by Suryanarayana et al. (2014); Ulaganathan et al. (2014); Bisht et al. (2015).

\subsection{Genetic advance}

Genetic advance is relative increase in mean value of population after selection. High values of genetic advance was recorded for biological yield per plant (23.22) followed by plant height (16.31), days to $50 \%$ flowering (15.16), flag leaf area (6.57), harvest index (5.81), days to maturity (5.62) and ear length (4.74). Lowest value was recorded for 1000 seed weight (0.46) followed by number of fingers ear ${ }^{-1}$ (1.18) and productive tillers plant ${ }^{-1}$ (1.47). High genetic advance has also been reported by Lule et al. (2012); Kadar et al. (2013); Suryanarayana et al. (2014) plant height, days to $50 \%$ flowering and days to maturity.

High heritability coupled with high genetic advance were observed for biological yield plant ${ }^{-1}$, plant height and days to $50 \%$ flowering. Direct selection for these characters would be effective as heritability and genetic advance might be due to additive gene interaction. While characters 1000 seed weight, fingers ear ${ }^{-1}$, productive tillers plant ${ }^{-1}$, number of leaves on main culm, grain yield plant ${ }^{-1}$, peduncle length, finger length and ear length exhibited high heritability and low genetic 
advance indicating the likehood of predominance of non additive gene interaction. Similar results were obtained by Lule et al. (2012); Kadar et al. (2013); Harti et al. (2015).

\section{Conclusion}

High magnitude of genotypic and phenotypic coefficient of variation were noticed for biological yield plant ${ }^{-1}$, finger length, productive tillers plant ${ }^{-1}$, grain yield plant ${ }^{-1}$ and peduncle length indicates higher variability among characters. Hence, these characters are more suitable for selection procedure. The estimate of high heritability coupled with high genetic advance was observed for biological yield plant ${ }^{-1}$, plant height and days to $50 \%$ flowering. Direct selection for these characters would be effective as heritability and genetic advance might be due to additive gene interaction.

\section{References}

Allard, R.W., 1960. Principles of plant breeding. New York, John Wiley and Sons, 485.

Bisht, A., Jeena, A.S., Singh, N.K., Singh, S.P., 2015. Morphological characterization and genetic analysis of finger millet (Eleusine coracana (L.) Gaertn). Frontiers in Plant Science 3(1), 9-14.

Burton, G.W., Devane, E.W., 1953. Estimating heritability in tall fescues (Festuca arundinaceae) from replicated clonal material. Agricultural Journal 4, 478-481.

Cochran, W.G., Cox, M.G., 1992. Experimental Design, New York, USA; John Wiley sons Inc. 106-117.

Dapke, J.S., Shah, D.S., Pawar, G.N., Dhembre, V.M., Kumar, M., 2014. Genetic variability and character association over environment in pearl mille (Pennisetum Glaucum (L.) R. BR. under dryland conditions of gujarat. The Bioscan 9(2), 863-867.

Das, R., Sujatha, M., Pandravada, S.R., 2016. Assessment of variability, heritability, genetic advance in finger millet (Eleusine coracana Gaertn) germplasm lines. Environment and Ecology 34(4), 1829-1833.

Goswami, A.P., Prasad, B., Joshi, V.C., 2015. Characterization of finger millet [Eleusine coracana (L.) Gaertn.] germplasm for morphological parameters under field conditions. Journal of Applied and Natural Science 7(2), 836-838.

Harti, M., Jayarama, G., Vijaykumar, L., Mallikarjun, K., Basavaraja, T., 2015. Genetic variability and heritability for economic traits in references set of finger millet. Trends in Biosciences 8(5), 1306-1309.

Hayes, H.K., Immer, F.R., Smith, D.C., 1955. Methods of plant breeding. $2^{\text {nd }}$ ed. McGraw Hill Book company, Inc. Tokyo, 551.

Johnson, H.W., Robinson, H.F., Comstock, R.E., 1955. Estimation of genetic and environmental viability in soyabean. Agronomy Journal 47, 314-318.

Karad, S.R., Patil, J.V., 2013. Assessment of genetic diversity among finger millet (Eleusine coracana L.) genotypes. International Journal of Integrative sciences, Innovation and Technology 2(4), 37-43.

Kumari, S., Singh, S.K., 2015. Assesment of genetic diversity in promising finger millet [Eleusine coracana (L.) Gaertn] genotypes. The bioscan 10(2), 825-830.

Lule, D., Tesfaye, K., Fetene, M., De Villiers, S., 2012. Inheritance and association of quantitative traits in finger millet (Eleusine coracana subsp. Coracana) landraces collected from eastern and south eastern Africa. International Journal of Genetics 2(2), 12-21.

Owere, L., Tongoona, J., Derera, J., Wanyera, N., 2015. Variability and traits relationships among finger millet accessions in Uganda. Uganda Journal of Agricultural Sciences 16(2), 161-176.

Patil, A.S., Mane, V.A., 2013. Studies of the genetic variation of yield and contributing traits in finger millet (Eleusine coracana (L.) Gaertn). Progressive Research 8, 526-528.

Suryanarayana, L., Shekhar, D., Rao, N.V., 2014. Genetic variability and divergence studies in finger millet (Eleusine Coracana (L.) Gaertn]. International Journal of Current Microbiology and Applied Sciences 3, 931-936.

Ulaganathan, V., Nirmalakumari, A., 2014. Genetic variability and correlation studies for quantitative traits in finger millet [Eleusine Coracana (L.) Gaertn] germplasm. The Ecoscan 5(6), 21-25. 